\title{
Development of an Instructional Design Model for Mobile Blended Learning in Higher Education
}

\author{
https://doi.org/10.3991/ijet.v14i16.10633 \\ I Kadek Suartama $\left({ }^{\square}\right)$ \\ Universitas Negeri Malang, Malang, Indonesia \\ Universitas Pendidikan Ganesha, Singaraja, Indonesia \\ ik-suartama@undiksha.ac.id \\ Punaji Setyosari, Sulthoni, Saida Ulfa \\ Universitas Negeri Malang, Malang, Indonesia
}

\begin{abstract}
The development of information and communication technology has brought a surprise and revolutionary challenge to the idea and practice of traditional education. Mobile internet technology has become the main promoter and accelerator to apply the concept of mobile learning. Mobile technology offers new opportunities to integrate face-to-face learning and online learning methods. We see a tendency to use blended learning scenarios by combining various forms of learning and integrating a variety of ways to access content using mobile technology. The objective of this study is to develop a mobile blended learning design that can systematically guide the instructor or lecturer in the lecturing processes. By combining the ideas of mobile learning and blended learning, mobile blended learning design has been developed. Implementing research and development (R\&D) method, the mobile blended learning design has been constructed through designing process and validation by experts. This instructional design has feasibility to use in learning; therefore, it effectively increases the popularity of mobile blended learning.
\end{abstract}

Keywords-Instructional design, mobile learning, blended learning, mobile blended learning, instructional media

\section{Introduction}

Nowadays, information and communication technology products in the form of mobile communication devices have become primary need since they offer a new paradigm in connectivity, communication, and collaboration in our daily lives. They allow people to use both in the office, at home, or during their trip [1]. They influence wide sectors of our lives including in the field of education. The presence of mobile technology is a great opportunity to provide a relevant and interesting learning experience [2]. Technology development has created new products like mobile phones, electronic devices (gadgets), cloud computing, wireless networking, etc. which become the main promoter and accelerator to apply the concept of mobile learning [3]. 
Mobile learning is the use of mobile technology in learning which can effectively improve learning and teaching through the context of learning, communication, collaboration, as well as enable the students to access the contents many times [4]. Mobile learning is focused on mobile computing devices that reflect the importance of functional components for typical mobile devices whice utilized in learning [5]. Furthermore, Elfeky \& Yakoub Masadeh [6] state that mobile learning is a powerful learning method to increase student engagement in accordance with the characteristics of the students themselves and enhance their learning experience more widely because of the quality, mobility and its supporting platform.

The mobile device can bridge and connect the informal and formal learning experiences and enable the design of learning that provides authentic learning experiences. Informal learning is marked with a learning experience that occurs outside the classroom setting which commonly includes accidental events that can be captured through students' smartphone equipped with quality cameras, microphones, and recording metadata and then instantly shared through the internet. Meanwhile, formal learning is generally marked with learning activities designed by the teacher and carried out in a classroom setting, for example, associated with formative or summative assessment [7]. Basically, the mobile internet can optimize the traditional model of online learning so that it will step forward to conduct more learning activities outside the classroom. Recent developments in mobile technology increasingly allow for support of mobile learning and provide great advantages for spontaneous learning situations. Additionally, mobile technology offers new opportunities to integrate the spontaneous learning in more formal learning scenarios. We see a tendency to use blended learning scenarios by combining various forms of learning and integrating a variety of ways to access content, such as web-based, desktop, and mobile [8].

Blended learning aims to find the right balance between face-to-face and online methods [9]. Blended learning changes the passive students who usually only receive knowledge, which is the hallmark of the traditional teaching model, into the active students who construct their own knowledge [10], [11]. At the moment, blended learning ability has been well understood, and its flexibility, ease of access, and integration of advanced multimedia and high technology have been used as material consideration [12]. Mobile blended learning refers to the learning design that includes the use of mobile devices for specific learning activities combined with other educational technologies approaches. Compared with the use of the general concept of blended learning, the addition of mobile highlights different learning activities for each technology used in the learning scenario [13].

Research shows that mobile learning can increase student participation and achievement as well as help them learn. Learners do not only learn in a formal learning environment, but they can also learn throughout their lives using different tools and technologies [6], [14] - [16]. Other studies, show the mobile device is like a doubleedged sword in the sense of giving a chance to learn the positive experiences and negative activities. Lack of mobile learning design makes learners doing unnecessary activities for instance watching movies, listening music, playing games, chatting on social networks, an so on. These activities may lead to reduce academic performance and productivity [17]. Mobile learning can also provide other negative effects, 
especially the occurrence of students' cognitive overload when the learning design used is inappropriate way [18]. Masarweh [19] finds that some mobile learning applications do not have a systematic methodology and appropriate design.

Pedagogical factors have the greatest influence on the success, intentions and behavior of students to adopt mobile learning which includes the provision of more diverse teaching contents/materials, strategies, and learning environments that can improve student learning performance [20]. Systematic planning is required to determine and define the pedagogical factors in a learning design. Instructional system design is a well structured system of developing instructional materials that comprise of goals, relevant teaching strategies, systematic feedback, and evaluation. It can also be defined as the science of creating detailed specifications for the design, development, evaluation, and maintenance of teaching materials that facilitate learning and performance [21]. Instructional design model is a systematic tool that helps designers understand the variables related to learning and/or guide them through the design process of learning activities [22]. Some function of instructional system design are a guideline as well as rules for developing courses that aim to improve learning, and influence the activities of students, motivation, and attitudes in such a way that they can achieve a deeper understanding of the materials to be learned [23].

This study focuses on the development of an instructional system design of mobile blended learning design. The purpose of this study is to create a learning environment that provides opportunities for learners to learn based on the learning objectives of the relevant particularities of learning which utilized physical and digital environment. Mobile blended learning design includes methodology, skills, and techniques needed to develop effective learning solutions. In this study, mobile blended learning design is developed using a Moodle Learning Management System platform. It can effectively encourage the implementation of mobile blended learning model and make it more convenient for use by learners.

\section{Relevant Literature}

\subsection{Overview of Mobile blended learning}

Mobile blended learning is a special form of blended learning and a term used to describe the learning opportunities where mobile technology supports situational learning activities and combines the mobility of students into the conception of learning opportunities [24]. Another definition of mobile blended learning is a blended learning system with an assistance of using mobile communication technology where its characteristics are mobility and situational learning [25]. Mobility in the context of learning means that learners can move from the standard learning environment, do not use fixed learning resources, such as desktop computers, etc. Mobile learning does not merely refer to the learners are learning to move; more specifically it refers to the place of students who are not fixed, mobile devices can be used either outside the classroom or in the classroom. Situational learning is reflected in the function of context-aware that can provide the filtered learning content and most appropriate contents for users. 
Through a variety of contexts for students' information perception and treatment analysis, understanding students' behavior and needs will provide the use of highest performance.

\subsection{Instructional design development model for Mobile blended learning}

Creating a successfull instructional system design of mobile blended learning requires systematic planning. It might use combination of several models. There is a lot of mobile blended learning models proposed by the experts. Huang \& Zhang [26] propose a blended learning curriculum design model. Their framework is divided into three stages:

1. Pre-analysis

2. Design activities and resources

3. Design of learning assessment

Hack [27] offers a new model for instructional design of blended learning which is called a pyramid model with 5 levels. Level 1 includes: assessing needs, analyzing learners, stating goals, analyzing resources; level 2 includes: developing objectives, blending \& sequencing, designing learning activities; level 3 includes: developing assessment strategies, delivering \& getting feedback; and level 4 includes: analyzing and revising.Furthermore, Biech [28] states that there are three steps to be followed in developing instructional system design of mobile blended learning namely:

1. Validating the learning goals and assessment techniques

2. Mapping the learning objectives of delivering technology using the Bloom's digital learning taxonomy

3. Reversing/mixing classes to maximize the impact of the collaboration. Learning scenarios must demonstrate a link between

(a) the purpose referring to Bloom

(b) assessment

(c) the content and activities of offline/online offered to the students [29].

Design of the learning process can be presented through two models; namely topdown model and the matrix model. Top-down model does not connect every component of instructional (objectives, information, practices/activities, and assessment) of each other, so there is no right alignment between each of these elements. Meanwhile, matrix model represents the harmony between the components of instructional and tends to be more effective in design to the alignment of instructional material [21].

\subsection{Design of Mobile blended learning system Based on Moodle LMS}

Mobile blended learning system can be developed using the Moodle platform. Moodle stands for "Modular Object-Oriented Dynamic Learning Environment". Moodle has become a term synonymous with a software package designed to help educators create quality online learning and it is a Learning Management System 
(LMS) [30]. Since Moodle was introduced as an open source learning software, blended learning has been developed as another method of teaching in addition to the traditional face-to-face learning [31].

Researches have proven that the use of Moodle LMS can improve learning outside the classroom and provide a positive influence on students' thinking and innovation skills [32] - [35]. In addition, it is proven that blended learning easily to be delivered when using Moodle as LMS. Moodle LMS that is built on sociocultural constructivism [36] enable to create a student-centered approach in which students and instructors get involved in online class by implementing constructive learning activities. Research by Matthew Perkins [37] aims to demonstrate the benefits of LMS which allows teachers to easily send assignments, lesson plans, announcements, and other instructional documents. Learning highlights the advantages of using one of LMS open-source software for free which provides a complete set of features and ease to use is Moodle. Perkins study describes how Moodle has improved student performance by providing and arranging communication between parents, students, teachers, administrators, and community. Using LMS can help reduce interference and barriers to learning and improve communication with colleagues, students, and parents. The reason behind the use of Moodle in blended learning is the assistance offered to the instructor and student needs [38].

Mobile blended learning is an aspect in restructuring learning strategies and showing more attention to the students, and giving them more spaces to engage effectively in the learning process, it is implemented through the use of Moodle open source e-learning platform. There are various features of Moodle LMS that can be used to support the application of mobile blended learning. These features consist of:

1. Common features

2. The administrative features

3. The course development and management features [39].

In detail, these features are presented in Table 1.

Table 1. Features of Moodle LMS

\begin{tabular}{|l|l|l|}
\hline \multicolumn{1}{|c|}{ General Features } & \multicolumn{1}{|c|}{ Administrative Features } & \multicolumn{1}{c|}{$\begin{array}{c}\text { Course Development and } \\
\text { Management Features }\end{array}$} \\
\hline $\begin{array}{l}\text { Modern, easy to use interface } \\
\text { Personalized Dashboard }\end{array}$ & Customisable web design and & $\begin{array}{l}\text { Direct learning paths } \\
\text { Collaborative tools and }\end{array}$ \\
layout & Secure authentication and mass & Embed external resources \\
activities & enrollment & Multimedia integration \\
All-in-one calendar & Multilingual capability & Group management \\
Convenient file management & Bulk course creation and easy & Marking workflow \\
Simple and intuitive text editor & backup & In-line marking \\
Notifications & Manage user roles and & Peer and self-assessment \\
Track progress & permissions & Integrated badges \\
& Supports open standards & Outcomes and rubrics \\
& High interoperability & Competency-based marking \\
& Simple plug-in management & Security and privacy \\
& Regular security updates & \\
& Detailed reporting and logs & \\
\hline
\end{tabular}


Learning (course) in Moodle is an area where a teacher adds resources and activities to be completed by the students as presented in Table 2 .

Table 2. Resources and Activities in Moodle LMS

\begin{tabular}{|l|l|l|}
\hline \multicolumn{1}{|c|}{ Resources } & \multicolumn{2}{c|}{ Activities } \\
\hline Book & Assignments & Lesson \\
File & Chat & (LTI) External Tool \\
Folder & Choice & Quiz \\
IMS Content Package & Satabase & SCORM \\
Label & Feedback & Survey \\
Page & Forum & Wiki \\
URLs & Glossary & Workshop \\
\hline
\end{tabular}

\section{$3 \quad$ Method}

\subsection{Research Design}

Research on instructional design models can be classified into three types: model development, model validation, and model usage. This study involves the first two and largely follows the methodology for model development and model validation described by Richey \& Klein [40] who notes that the instructional design models can be developed by means of theoretical or practical approaches, or both. Theoretical approaches synthesize the relevant literature, while practical approach utilizes simulation design tasks or real-life design projects [41]. Instructional design model for mobile blended learning in this study was developed from the synthesis of the relevant literature, the task simulated design and project data designed from real life.

Furthermore, the model can be validated by referring to the suitability of the model components and utility models with respect to the objectives [42]. The validation process of instructional design model is planned carefully by collecting and analyzing empirical data to:

1. Provide support for each component of the model

2. To confirm its usefulness in practice [43].

Instructional design model validation can be conducted either internally or externally or through the use of both methods. Internal model validation addresses the integrity and usefulness of the model [40]. Integrity refers to how valid model of the component or process of a model; and the usefulness of the model shows how effective the model can help designers understand the variables related to learning and/or guide them through the process of analyzing, designing, developing, and evaluating learning products [22]. Common internal validation method is an expert review and usability test models. External validation of the model related to the effects of the use of models concerning on the quality of instructional design products are made and the benefits to students, clients, or organization. Instructional design model validation for mobile blended learning in this study underwent internal validation through reviews of experts. 


\subsection{Procedures}

The mobile blended learning design was developed which refers to the design model of blended learning which proposed by Huang \& Zhang [26], Hack [27], and Han, Tian, $\&$ Cheng [44]. Based on these three models, the blended learning curriculum design is divided into three stages:

1. Pre-analysis

2. Designing activities and resource

3. Designing learning assessment

This blended mobile learning design is guided by the basic theory of pedagogy, supported by Moodle LMS function, and makes time a horizontal coordinate. We combined Moodle LMS and traditional classroom, optimized and designed mobile blended learning based on Moodle LMS in terms of students and lecturer. The development of mobile blended learning design was carried out in the Instructional Media course in the Department of Primary School Teacher Education of the Faculty of Education, Universitas Pendidikan Ganesha, Singaraja, Bali, Indonesia. The procedures as shown in Figure 1.

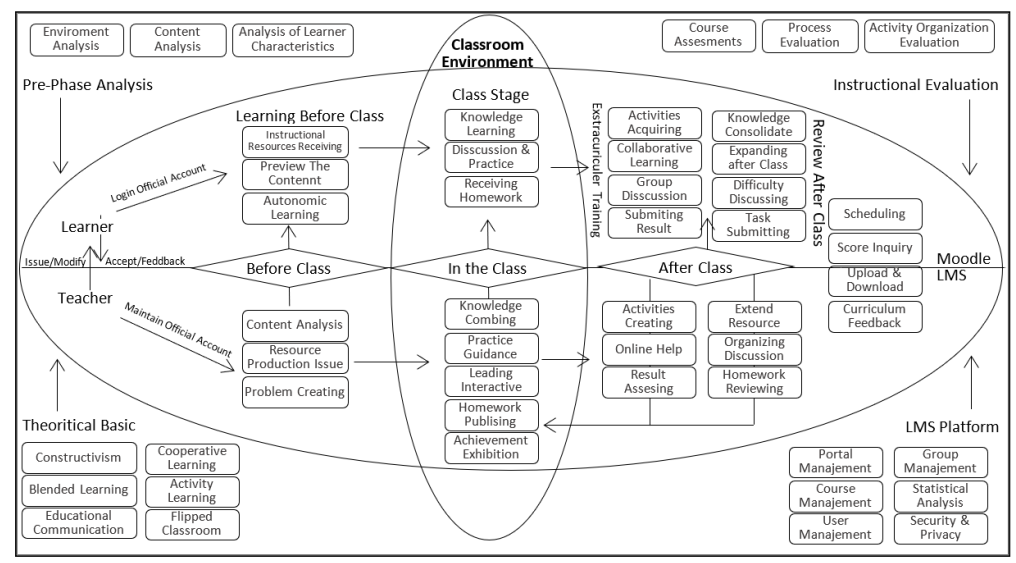

Fig. 1. Procedures of Mobile Blended Learning Design Using Moodle LMS (adapted from Han, Tian \& Cheng [44])

The first stage is pre-analysis: To ascertain whether blended learning can be used, some observations and analyses need to be done. This analysis consists of three components:

1. Analysis of the characteristics of learners that includes prior knowledge, learning styles, learning preferences, etc.

2. Analysis of learning objects that define what should be taught about knowledge taxonomic

3. Analysis of blended learning environment, in terms of knowing the environmental features. 
The purpose of this phase is to identify the level of proficiency of learners and outline the task of learning that will be a sound foundation for the organization of learning activities. Pre-analysis of transactions is carried out through observation, documentation studies and questionnaires filled out by students.

The second stage is design of events/activities and resources: Blended learning facilitates access to diverse learning materials and access the contents through the internet anytime and anywhere. The design of activities and resources can be divided into pre-classroom learning, instructional phase, reviews after class and extracurricular activities, training, and implementation. In before-classroom, the lecturer gives a framework of new learning content and difficulty and provide relevant learning materials, instructional videos and other multimedia courseware by online. In classroom, the lecturer systematically summarizes the knowledge and presents relevant information needed for the class by offline/onsite. After class, the lecturer gives a summary of knowledge, extracurricular activities, experiments and extracurricular learning materials, submission, test and tasks as well as provides corrections via Moodle LMS. At the same time, the lecturer will facilitate an online discussion group.

The third stage is design evaluation: These activities include curriculum evaluation, process evaluation, and evaluation activities of the organization, and they are respective measured through online testing, the situation in the class discussion and review of experimental activity.

\subsection{Product Validation}

Instructional system design validation that conducted by experts which have expertises in the area of instructional system design field. Meanwhile, it is also validated by practitioners of instructional design who were selected based on certain criterias. The validation by experts is important to get insight for improvements mobile blended learning design as well as obtaining a guarantee that the design developed is feasible to be implemented in the learning context.

Instrument: The question types of validation instruments were closed-ended and open-ended questions. Closed-ended questions employed a 5 point Likert scale were prepared based on standards/rubric for comprehensive e-learning instructional design developed by Debattista [45] as presented in Table 3. Meanwhile, questionnaire with open-ended questions were used to request an opinion or advice from the experts on mobile blended learning design developed.

Data analysis: Data obtained from the validation of mobile blended learning design is classified into two categories, namely quantitative and qualitative data. The qualitative data include criticism and suggestions put forward by experts and practitioners of instructional design. These data were collected and summarized to improve the design of mobile blended learning developed. Meanwhile, quantitative data include a score on each item of instrument that has been filled by experts and practitioners of instructional design. Descriptive statistical analysis techniques were used to provide the value/quality of mobile blended learning design developed. Scores are summed up and averaged, and then converted into a value by using the table criterion-referenced test 5 scale adapted from Sukardjo [46] as presented in Table 4. 
Table 3. Standard/Rubric Comprehensive for Mobile Blended Learning Design Assessment

\begin{tabular}{|c|c|c|}
\hline Main Standards & \multicolumn{2}{|c|}{ Specific Standards } \\
\hline Instructional design & $\begin{array}{l}\text { Structure of learning } \\
\text { Learning aims and objectives }\end{array}$ & $\begin{array}{l}\text { Learning outcomes } \\
\text { Instructional strategies and } \\
\text { methods }\end{array}$ \\
\hline Course opening & $\begin{array}{l}\text { Accessibility } \\
\text { Role } \\
\text { Description } \\
\text { Behavior }\end{array}$ & $\begin{array}{l}\text { Integrity } \\
\text { Technical competences } \\
\text { Ownership }\end{array}$ \\
\hline Assessment of learning & $\begin{array}{l}\text { Goals and objectives } \\
\text { Strategies } \\
\text { Grading }\end{array}$ & $\begin{array}{l}\text { Feedback } \\
\text { Management }\end{array}$ \\
\hline Interaction and community & $\begin{array}{l}\text { Fostering } \\
\text { Management }\end{array}$ & Peer learning \\
\hline $\begin{array}{l}\text { Instructional resources for teaching } \\
\text { and learning }\end{array}$ & $\begin{array}{l}\text { Provision } \\
\text { Application } \\
\text { Entitlement }\end{array}$ & $\begin{array}{l}\text { Variety } \\
\text { Openness } \\
\text { Academic integrity }\end{array}$ \\
\hline Learner support & $\begin{array}{l}\text { Instructional support } \\
\text { Academic support }\end{array}$ & $\begin{array}{l}\text { Technical support } \\
\text { Administrative support }\end{array}$ \\
\hline Technology design & $\begin{array}{l}\text { Support } \\
\text { Centricity } \\
\text { Openness } \\
\text { Authentication }\end{array}$ & $\begin{array}{l}\text { Access } \\
\text { Interface } \\
\text { Investment } \\
\text { Management }\end{array}$ \\
\hline Course closing & $\begin{array}{l}\text { Assessment } \\
\text { Resolution }\end{array}$ & Archiving \\
\hline Instructional design cycle & $\begin{array}{l}\text { Academic reviews } \\
\text { Technical review }\end{array}$ & Administrative review \\
\hline
\end{tabular}

Table 4. Score Conversion to Value on a 5 Scale

\begin{tabular}{|l|l|l|}
\hline \multicolumn{1}{|c|}{ Score/Category } & \multicolumn{1}{c|}{ Score } \\
\cline { 2 - 3 } & \multicolumn{1}{c|}{ Pattern } & \multicolumn{1}{c|}{ Calculation } \\
\hline Excellent & $\mathrm{X}>\bar{X}_{i}+1,80 \mathrm{Sdi}$ & $\mathrm{X}>4,21$ \\
\hline Very good & $\bar{X}_{i}+0,60 \mathrm{Sdi}<\mathrm{X} \leq \bar{X}_{i}+1,80 \mathrm{Sdi}$ & $3,40<\mathrm{X} \leq 4,21$ \\
\hline Good & $\bar{X}_{i}-0,60 \mathrm{Sdi}<\mathrm{X} \leq \bar{X}_{i}+0,60 \mathrm{Sdi}$ & $2,60<\mathrm{X} \leq 3,40$ \\
\hline Average & $\bar{X}_{i}-1,80 \mathrm{Sdi}<\mathrm{X} \leq \bar{X}_{i}-0,60 \mathrm{Sdi}$ & $1,79<\mathrm{X} \leq 2,60$ \\
\hline Poor & $\mathrm{X} \leq \bar{X}_{i}-1,80 \mathrm{Sdi}$ & $\mathrm{X} \leq 1,79$ \\
\hline
\end{tabular}

Where:

The mean ideal $\left(\bar{X}_{i}\right) \quad=1 / 2 \times$ (maximum score + minimum score $)$

Standard deviation ideal (Sdi) $=1 / 6 \times$ (maximum score - minimum score)

Maximum score $\quad=5$

Minimum score $\quad=1$

$\bar{X}_{i} \quad=1 / 2 \times(5+1)=3$

Sdi $\quad=1 / 6 \times(5-1)=0.67$

$\mathrm{X} \quad=$ Actual Score

To locate the average score (mean score) of an assessment of the product that has been developed, the following formula is used:

$$
\bar{X}_{i}=\frac{\sum X}{n}
$$


Where:

$\bar{X}_{i} \quad=$ Mean score

$\sum X=$ Total score

$n \quad=$ Number of respondents/validators

In this study, the feasibility of a minimum set value of "Very good", as the result of a good assessment by experts and practitioners of instructional design. If the results of the final assessment (overall) at least got an "Very good" by experts and practitioners, the instructional design of the development is already considered feasible in learning.

\section{$4 \quad$ Results}

\subsection{Results of Pre-Analysis}

The results of this pre-analysis were qualitative data obtained through observation, documentation studies and questionnaires filled out by students. Results of pre-analysis consist of

- The characteristics of learners

- The characteristics of the learning object or course

- The condition of the learning environment

Students of the Department of Primary School Teacher Education of the Faculty of Education, Universitas Pendidikan Ganesha were confirmed have mobile devices. They also have a smartphone running either on Android and iOS operating system and most of them prefer to access information through their smartphones rather than using a laptop or PC. They are also happy if they can independently explore various learning resources available in a spacious environment through social interaction with various parties that have direct or indirect relevance to the material being studied.

Instructional Media course has a fairly extensive range of materials that have the theoretical concept and practical and empirical material nature. Specifically, the purpose of Instructional Media course is that students have the knowledge, skills, and attitudes in the field of design, development, utilization, evaluation, and assessment of media in learning. Instructional Media course with 3 credits ( 1 credit is equivalent to 50 minutes) means that the learning time provided in the class is very less compared to the broad material that this course requires. Therefore, lectures outside the classroom (blended learning) become the perfect solution for the completion of this course.

To support Instructional Media course in terms of environment and infrastructure, the Department of Primary School Teacher Education of the Faculty of Education, Universitas Pendidikan Ganesha has had already one computer laboratory with 36 PCs, 16 mobile devices (iPad), and WIFI for internet connection. In addition, almost all the lecturers and students are equipped with mobile devices (smartphones). They are also able to use a computer and internet access which is very appropriate to be the motor of the implementation of mobile blended learning design. 


\subsection{Final design of Mobile blended learning}

Developed instructional system design of mobile blended learning is described in one matrix as shown in Figure 2. The formulation of learning objectives taxonomy refers to the learning objectives of the revised taxonomy by Bloom [47], such as; remembering (C1), understanding (C2), applying (C3), analyzing (C4), evaluating (C5), and creating (C6). Stages of blended learning consist of online activities (before class and after class) and offline activities (in class and onsite). The final section describes the utilization of Moodle LMS features (Mob App) including resources and activities.

Table 5. Mobile Blended Learning Design in Instructional Media Course

\begin{tabular}{|c|c|c|c|c|c|}
\hline \multicolumn{6}{|c|}{ Matrix of Mobile Blended Learning Design - Instructional Media Course } \\
\hline \multicolumn{6}{|c|}{$\begin{array}{l}\text { Goal: Students have the knowledge, attitudes, and skills in the field of design, development, utilization, } \\
\text { evaluation, and assessment of media in learning. }\end{array}$} \\
\hline \multirow[t]{2}{*}{ Objectives } & \multicolumn{3}{|c|}{ Stages of Learning (Blended Learning) } & \multicolumn{2}{|c|}{$\begin{array}{l}\text { Features of Moodle } \\
\text { LMS (Mob.App) }\end{array}$} \\
\hline & $\begin{array}{l}\text { Before Class } \\
\text { (Online) }\end{array}$ & $\begin{array}{c}\text { In the } \\
\text { Class/Onsite } \\
\text { (Offline) }\end{array}$ & $\begin{array}{l}\text { After Class } \\
\text { (Online) }\end{array}$ & Resource & Activities \\
\hline $\begin{array}{l}\text { Explaining the } \\
\text { basic concepts } \\
\text { and instructional } \\
\text { media } \\
\text { classification } \\
(\mathrm{C} 1, \mathrm{C} 2)\end{array}$ & $\begin{array}{l}\text { Orientation for } \\
\text { students } \\
\text { Accessing digital } \\
\text { learning resources } \\
\text { (handouts, e- } \\
\text { module) } \\
\text { Content preview } \\
\text { Students grouping }\end{array}$ & \begin{tabular}{|l|} 
Reviewing basic \\
concepts of \\
instructional \\
media through \\
expository method \\
and debriefing \\
Group activities \\
(Completing \\
Student \\
Worksheet / MFI)
\end{tabular} & $\begin{array}{l}\text { Looking for and } \\
\text { collecting information } \\
\text { Discussing the theory } \\
\text { learned, discussing the } \\
\text { case, answering } \\
\text { questions or discussing } \\
\text { problems/tasks } \\
\text { Community social } \\
\text { network } \\
\text { Conclusion }\end{array}$ & $\begin{array}{l}\text { Book } \\
\text { File } \\
\text { URL } \\
\\
\end{array}$ & $\begin{array}{l}\text { Forum } \\
\text { Glossary } \\
\text { Feedback }\end{array}$ \\
\hline $\begin{array}{l}\text { Characteristics } \\
\text { of instructional } \\
\text { media types } \\
(\mathrm{C} 2, \mathrm{C} 3)\end{array}$ & $\begin{array}{l}\text { Orientation of } \\
\text { learning } \\
\text { Accessing digital } \\
\text { learning resources } \\
\text { (handouts, e- } \\
\text { module, multimedia } \\
\text { interactive learning) } \\
\text { Content preview } \\
\text { Work assignments }\end{array}$ & $\begin{array}{l}\text { Carrying out an } \\
\text { observation/field } \\
\text { study about the } \\
\text { type and } \\
\text { characteristics of } \\
\text { learning media to } \\
\text { the } \\
\text { school/learning } \\
\text { resource center } \\
\text { (onsite). Data } \\
\text { (photo/video) are } \\
\text { recorded using } \\
\text { students' } \\
\text { smartphones } \\
\text { Preparation of } \\
\text { reports }\end{array}$ & $\begin{array}{l}\text { Discussing the theory } \\
\text { learned, discussing the } \\
\text { case, and the problems } \\
\text { faced by students in } \\
\text { the field either } \\
\text { individually or in } \\
\text { groups } \\
\text { Collecting reports on } \\
\text { the results of the } \\
\text { observation/field study }\end{array}$ & $\begin{array}{l}\text { IMS } \\
\text { Content } \\
\text { Package } \\
\text { File } \\
\text { URL } \\
\end{array}$ & $\begin{array}{l}\text { Forum } \\
\text { Chatting } \\
\text { Assignment } \\
\text { : file } \\
\text { submission } \\
\text { s }\end{array}$ \\
\hline $\begin{array}{l}\text { Instructional } \\
\text { media } \\
\text { management } \\
(\mathrm{C} 3)\end{array}$ & $\begin{array}{l}\text { Orientation of } \\
\text { learning } \\
\text { Accessing digital } \\
\text { learning resources } \\
\text { (handouts, e- } \\
\text { module) } \\
\text { Content preview }\end{array}$ & $\begin{array}{l}\text { Presentation of the } \\
\text { report and } \\
\text { discussion } \\
\text { Examining the } \\
\text { media } \\
\text { management } \\
\text { concept of }\end{array}$ & $\begin{array}{l}\text { Discussing the theory } \\
\text { learned, discussing the } \\
\text { case, answering } \\
\text { questions or discussing } \\
\text { issues } \\
\text { Completing exercises }\end{array}$ & $\begin{array}{l}\text { Page } \\
\text { File } \\
\text { URL }\end{array}$ & $\begin{array}{l}\text { Live video } \\
\text { conference } \\
\text { Forum } \\
\text { Quiz: essay } \\
\text { / short } \\
\text { answer / } \\
\text { true-false / }\end{array}$ \\
\hline
\end{tabular}




\begin{tabular}{|c|c|c|c|c|c|}
\hline & & $\begin{array}{l}\text { learning through } \\
\text { expository method } \\
\text { and debriefing }\end{array}$ & $\begin{array}{l}\text { Students who have not } \\
\text { managed to do the } \\
\text { exercise will get } \\
\text { enrichment }\end{array}$ & & $\begin{array}{l}\text { multiple } \\
\text { choice } \\
\text { Feedback } \\
\text { Lesson }\end{array}$ \\
\hline $\begin{array}{l}\text { Development of } \\
\text { instructional } \\
\text { media (needs } \\
\text { analysis phase of } \\
\text { learning media) } \\
(\mathrm{C} 3, \mathrm{C} 4)\end{array}$ & $\begin{array}{l}\text { Orientation of } \\
\text { learning } \\
\text { Accessing digital } \\
\text { learning resources } \\
\text { (handouts, e- } \\
\text { module) } \\
\text { Content preview }\end{array}$ & $\begin{array}{l}\text { Holding a media, } \\
\text { identifying needs } \\
\text { in an educational } \\
\text { environment } \\
\text { through } \\
\text { observation/survey } \\
\text { or observation, } \\
\text { interview or } \\
\text { discussion about } \\
\text { education issues }\end{array}$ & $\begin{array}{l}\text { Discussing the theory } \\
\text { learned, discussing the } \\
\text { case, and the problems } \\
\text { faced by students in } \\
\text { the field }\end{array}$ & $\begin{array}{l}\text { Label } \\
\text { Page }\end{array}$ & $\begin{array}{l}\text { Wiki } \\
\text { Chatting }\end{array}$ \\
\hline $\begin{array}{l}\text { Development of } \\
\text { instructional } \\
\text { media: } \\
\text { The instructional } \\
\text { media design } \\
\text { stage } \\
\text { The learning } \\
\text { media } \\
\text { production stage } \\
\text { (C6) }\end{array}$ & $\begin{array}{l}\text { Orientation of } \\
\text { learning } \\
\text { Accessing digital } \\
\text { learning resources } \\
\text { (handouts, e- } \\
\text { module) and the } \\
\text { Student Worksheet } \\
\text { (MFIs) } \\
\text { Content preview }\end{array}$ & $\begin{array}{l}\text { Developing } \\
\text { learning media } \\
\text { design in the } \\
\text { classroom } \\
\text { through: } \\
\text { Workshop } \\
\text { Project-based } \\
\text { learning } \\
\text { Producing media } \\
\text { based on a design } \\
\text { that has been } \\
\text { made at the } \\
\text { workshop or at } \\
\text { home } \\
\end{array}$ & $\begin{array}{l}\text { Discussing the } \\
\text { problems faced by } \\
\text { students in developing } \\
\text { products with the } \\
\text { lecturer } \\
\text { Collecting } \\
\text { instructional media } \\
\text { design products }\end{array}$ & $\begin{array}{l}\text { File } \\
\text { URL }\end{array}$ & $\begin{array}{l}\text { Workshop } \\
\text { Chatting } \\
\text { Assignment } \\
\text { : file } \\
\text { submission } \\
\text { s }\end{array}$ \\
\hline $\begin{array}{l}\text { Development of } \\
\text { instructional } \\
\text { media: } \\
\text { Evaluation } \\
\text { phase of } \\
\text { instructional } \\
\text { media } \\
\text { (C5) }\end{array}$ & $\begin{array}{l}\text { Orientation of } \\
\text { learning } \\
\text { Accessing digital } \\
\text { learning resources } \\
\text { (handouts, e- } \\
\text { module) } \\
\text { Content preview }\end{array}$ & $\begin{array}{l}\text { Developing } \\
\text { evaluation } \\
\text { instruments of } \\
\text { learning media } \\
\text { Conducting } \\
\text { evaluation/validati } \\
\text { on of learning } \\
\text { media in famine } \\
\text { expert (expert } \\
\text { judgment) to } \\
\text { improve and } \\
\text { enhance the } \\
\text { relevant media to } \\
\text { be more effective } \\
\text { and efficient }\end{array}$ & $\begin{array}{l}\text { Discussing the } \\
\text { problems faced by } \\
\text { students in validating } \\
\text { the products with the } \\
\text { lecturer }\end{array}$ & $\begin{array}{l}\text { Folder } \\
\text { File } \\
\text { URL }\end{array}$ & $\begin{array}{l}\text { Wiki } \\
\text { Chatting }\end{array}$ \\
\hline $\begin{array}{l}\text { The use of } \\
\text { instructional } \\
\text { media } \\
(\mathrm{C} 1, \mathrm{C} 2, \mathrm{C} 3, \mathrm{C} 4, \\
\mathrm{C} 5, \mathrm{C} 6)\end{array}$ & $\begin{array}{l}\text { Orientation of } \\
\text { learning } \\
\text { Accessing digital } \\
\text { learning resources } \\
\text { (handouts, e- } \\
\text { module) }\end{array}$ & $\begin{array}{l}\text { Using } \\
\text { instructional } \\
\text { media products } \\
\text { that have been } \\
\text { developed in the } \\
\text { classroom } \\
\text { through: } \\
\text { Simulation } \\
\text { method } \\
\text { Demonstration } \\
\text { method }\end{array}$ & $\begin{array}{l}\text { Addressing issues of } \\
\text { learning media use }\end{array}$ & & $\begin{array}{l}\text { Online } \\
\text { discussion } \\
\text { forum }\end{array}$ \\
\hline Final Exam & & & $\begin{array}{l}\text { Answering questions } \\
\text { of the online Final } \\
\text { Exam }\end{array}$ & & $\begin{array}{l}\text { Quiz: } \\
\text { multiple } \\
\text { choice }\end{array}$ \\
\hline
\end{tabular}




\subsection{Results of validation}

Experts and practitioners of instructional design are employed as the research product validators in this study. Experts and practitioners of instructional design provide ratings, comments and suggestions revision related to the aspects of instructional design, course opening, assessment of learning, interaction and community, instructional resources for teaching and learning, learner support, technology design, course closing, and instructional design cycle. Results of the assessment by the experts and practitioners of instructional design to product development are presented in Table 5.

Table 5. Results of Expert and Practitioners Validation on Mobile Blended Learning Design of Instructional Media Courses

\begin{tabular}{|c|l|c|c|c|c|c|l|}
\hline \multirow{2}{*}{ No. } & \multicolumn{1}{|c|}{ Aspect } & \multicolumn{4}{|c|}{ Score } & & \\
\cline { 3 - 6 } & & $\begin{array}{c}\text { Validator } \\
\mathbf{1}\end{array}$ & $\begin{array}{c}\text { Validator } \\
\mathbf{2}\end{array}$ & $\begin{array}{c}\text { Validator } \\
\mathbf{3}\end{array}$ & $\begin{array}{c}\text { Validator } \\
\mathbf{4}\end{array}$ & Average & Category \\
\hline 1. & Instructional design & 4.5 & 5 & 4 & 5 & 4.6 & Excellent \\
\hline 2. & Course opening & 4.6 & 4.7 & 4.3 & 5 & 4.7 & Excellent \\
\hline 3. & Assessment of learning & 5 & 4.8 & 4 & 5 & 4.7 & Excellent \\
\hline 4. & Interaction and community & 4.7 & 5 & 4.7 & 5 & 4.9 & Excellent \\
\hline 5. & $\begin{array}{l}\text { Instructional resources for } \\
\text { teaching and learning }\end{array}$ & 5 & 5 & 4 & 5 & 4.8 & Excellent \\
\hline 6. & Learner support & 4.8 & 5 & 4.5 & 4.8 & 4.8 & Excellent \\
\hline 7. & Technology design & 4.6 & 4.9 & 4 & 5 & 4.6 & Excellent \\
\hline 8. & Course closing & 5 & 5 & 4 & 4.7 & 4.7 & Excellent \\
\hline 9. & Instructional design cycle & 4 & 5 & 4 & 4.7 & 4.4 & Excellent \\
\hline & Average & 4.7 & 4.9 & 4.2 & 4.9 & & \\
\hline & Overall Average & & & & & $\mathbf{4 . 7}$ & Excellent \\
\hline
\end{tabular}

Based on the data presented in Table 5, it can be seen that mean score of all aspects of learning design assessment is 4.7. This score, referring to the table of conversion of quantitative data to qualitative data in 5 scale, is categorized into "Excellent", which means that the design of mobile blended learning developed is feasible to be applied in learning.

The suggestions for revision/improvement by the experts and practitioners of instructional design are

1. The general design of the developed mobile blended learning has been already good

2. There should be more learning activities that encourage independent learning for students

3. It needs to be emphasized on the mastery of higher competencies

\section{Discussions}

The procedure for developing a mobile blended learning design for Instructional Media courses includes three stages, namely pre-analysis, activity \& resource design, 
and learning assessment design. All these stages have been completed to produce an instructional system design of mobile blended learning that has met the eligibility criteria to be used in learning. The design has combined various methods of delivery, models of teaching and learning styles, and to introduce a selection of media and various forms of interaction between lecturers and students, and students to utilize the various features offered by mobile applications (Moodle LMS).

The advantages of instructional system design of mobile blended learning include giving an orientation before online classes activities that can provide an early opportunity for learners to prepare themselves both physically and mentally for participating in learning activities. Readiness to learn is a crucial factor and to be decisive for the success of learning [48]. In orientation of learning, lecturer gives clear instructions on how to access all elements of the online and offline learning environment. In addition, learners are warned about the regulations, policies, ethical and technical competencies needed to attain the goals of learning. Readiness to learn the form of knowledge and attitude provides a good basis for independent learning and reinforces the success of online learning [49]. If the student has already had a readiness in learning, online learning implementation will be efficient, effective, and economical [50],

Their diverse learning resources in terms of multimedia content and multi-modal delivery channels meet the preferences of learners. This is in accordance with what is disclosed by Caspi \& Gorsky [51] that the instructional media should be used based on the learning objectives and needs of the students so that it needs careful planning and may not use the same media but must be multi-media. Learning resources provided are also easily accessible with mobile devices and can be taken whenever it is required by the learners (learning allows instantaneous) to support individual learning and allow access to wider learning materials via a link to a URL/website.

Presentation of a variety of learning methods, both online and offline setting, based on consideration of the type of learning material course, a variety of learning media and the diversity of students' interest in learning. Their varied learning methods which can provide creativity modeling to students encourage students to be more active and can find an appropriate way of learning for them. Implementing the method which is in accordance with the material and the characteristics of the students will be able to create a conducive learning atmosphere and improve the achievement of the students [52]. In this instructional design, lecturer merely functions as a mediator, facilitator, and friend who makes the situation conducive to the learning productivity; as a result, students will ultimately have a deeper understanding. Another advantage of the design of this study is the diverse assessment methods and the access rights to their scores make students will be able to encourage themselves to continually study hard in order to excel in the classroom.

The design of mobile blended learning in Instructional Media course was emphasized to the maximum student activities to seek and find the materials (put the student as a subject of study). In the learning process, students do not only act as a receiver in passive way, they will construct their knowledge on their own way. The entire activities of the student were directed to seek and find the answers by themselves from something that is questionable, so as to foster self-confidence (self-belief), to 
develop intellectual abilities and mastery of higher competence as part of the mental process [53]. Thus, the mobile blended learning design can minimize the chances of negative events happen in the learning process by using mobile devices.

In this research there were many advantage in term of utilizing the mobile application of Moodle for instance

1. Being able to choose various available formats of learning activities, e.g., weekly format, the topical format and social formats

2. Flexibility in determining activities for learning, for example, community, journals, quizzes, a matter of choice, surveys, tasks, and chat

3. All class members both in the forum, journals, quizzes and assignments can be viewed on one page (and can be downloaded as a spreadsheet file)

4. Capable of displaying various user activities.

\section{Conclusion}

Utilization of mobile technology in education offers new opportunities to integrate face-to-face learning and online learning. The implementation of mobile learning and blended learning were not optimal due to a lack of a instructional system design. We see a tendency to use blended learning scenarios by combining various forms of learning and integrating a variety of ways to access content by using mobile technology. In this research we purpose instructional system design of mobile blended learning that can be used by educators who are interested in delivering their lesson through mobile blended learning. The development of mobile blended learning design had consisted of these following steps: a need analysis, design development activities, learning resources, determination of the learning evaluation, and validation by the experts. Assessments for instructional system design of mobile blended learning comprise of course opening, assessment of learning, interaction and community, instructional resources for teaching and learning, learner support, technology design, course selection, and instructional design cycle.

\section{$7 \quad$ Acknowledgement}

This study was supported by BPPDN scholarship from the Ministry of Research, Technology, and Higher Education of the Republic of Indonesia

\section{$8 \quad$ References}

[1] Harfoushi, O. (2017). Influence of Cloud Based Mobile Learning Applications on User Experiences: A Review Study in the Context of Jordan. International Journal of Interactive Mobile Technologies (IJIM), 11(4), 202-211. https://doi.org/10.3991/ijim.v11i4.6938

[2] McQuiggan, S., Kosturko, L., McQuiggan, J., \& Sabourin, J. (2015). Mobile Learning: A Handbook for Developers, Educators, and Learners. New Jersey: John Wiley \& Sons, Inc. https://doi.org/10.1002/9781118938942 
[3] Vlădoiu, M. (2012). Towards Instructional Design of Ubiquitous Learning Environments. International Journal of Computer\&OrganizationTrends-IJCOT, 2, 108-112. Retrieved from http://www.ijcotjournal.org/archive/ijcot-v2i4p305

[4] Cochrane, T., \& Narayan, V. (2016). Design Considerations for Mobile Learning. In C. Reigeluth, B. J. Beatty, \& R. Myers (Eds.), Instructional-Design Theories and Models. Routledge.

[5] Joo, Y. J., Kim, N., \& Kim, N. H. (2016). Factors predicting online university students' use of a mobile learning management system (m-LMS). Educational Technology Research and Development, 64(4), 611-630. https://doi.org/10.1007/s11423-016-9436-7

[6] Elfeky, A. I. M., \& Yakoub Masadeh, T. S. (2016). The Effect of Mobile Learning on Students' Achievement and Conversational Skills. International Journal of Higher Education, 5(3), 20-31. https://doi.org/10.5430/ijhe.v5n3p20

[7] Herrington, J., Mantei, J., Herrington, A., \& Ferry, B. (2008). New technologies, new pedagogies: mobile technologies and new ways of teaching and learning. In Annual Conference of the Australasian Society for Computers in Learning in Tertiary Education (pp. 419-427).

[8] Goh, T. T. (2010). Multiplatform e-learning systems and technologies: Mobile devices for ubiquitous ICT-based education. Information Science Reference-Imprint of: IGI Publishing Hershey, PA. USA. https://doi.org/10.4018/978-1-60566-703-4

[9] Morton, C. E., Saleh, S. N., Smith, S. F., Hemani, A., Ameen, A., Bennie, T. D., \& ToroTroconis, M. (2016). Blended learning: How can we optimise undergraduate student engagement? BMC Medical Education, 16(1). https://doi.org/10.1186/s12909-016-0716-Z

[10] Trujillo Maza, E. M., Gómez Lozano, M. T., Cardozo Alarcón, A. C., Moreno Zuluaga, L., \& Gamba Fadul, M. (2016). Blended learning supported by digital technology and competency-based medical education: a case study of the social medicine course at the Universidad de los Andes, Colombia. International Journal of Educational Technology in Higher Education, 13(1). https://doi.org/10.1186/s41239-016-0027-9

[11] Wichadee, S. (2017). A Development of the Blended Learning Model Using Edmodo for Maximizing Students' Oral Proficiency and Motivation. International Journal of Emerging Technologies in Learning, 12(2), 137-154. https://doi.org/10.3991/ijet.v12i02.6324

[12] Johnson, L., Adams Becker, S., Cummins, M., Estrada, V., Freeman, A., and Hall, C. (2016). NMC Horizon Report: 2016 Higher Education Edition. The New Media Consortium. Austin, Texas. https://doi.org/ISBN 978-0-9897335-5-7

[13] Christian Glahn, Marion R. Gruber, O. T. (2015). Beyond Delivery Modes and Apps: A Case Study on Mobile Blended Learning in Higher Education. (C) Springer International Publishing Switzerland 2015 G. Conole et Al. (Eds.): EC-TEL 2015, LNCS 9307, 127-140. https://doi.org/10.1007/978-3-319-24258-3 10

[14] Furió, D., Juan, M. C., Seguí, I., \& Vivó, R. (2015). Mobile learning vs. traditional classroom lessons: A comparative study. Journal of Computer Assisted Learning, 31(3), 189-201. https://doi.org/10.1111/jcal.12071

[15] García-Peñalvo, F. J., \& Conde, M. (2015). The impact of a mobile personal learning environment in different educational contexts. Universal Access in the Information Society, 14(3), 375-387. https://doi.org/10.1007/s10209-014-0366-z

[16] [16] Filali Marzouki, O., Khalidi Idrissi, M., \& Bennani, S. (2017). Effects of Social Constructivist Mobile Learning Environments on Knowledge Acquisition: A MetaAnalysis. International Journal of Interactive Mobile Technologies (IJIM), 11(1), 18. https://doi.org/10.3991/ijim.v11i1.5982

[17] Odukoya, J. A., Adekeye, O., \& Okunlola, S. (2017). Assessing the Effectiveness of Mobile Learning Devices in Tertiary Institutions: The Experience of Undergraduates in a Nigerian 
Private University. International Journal of Interactive Mobile Technologies (IJIM), 11(4), 160. https://doi.org/10.3991/ijim.v11i4.6828

[18] Chu, H. C. (2014). Potential negative effects of mobile learning on students' learning achievement and cognitive load-a format assessment perspective. Educational Technology and Society, 17(1), 332-344. https://doi.org/10.2307/jeductechsoci.17.1.332

[19] Masarweh, M. Al. (2019). Evaluating M-Learning System Adoption by Faculty Members in Saudi Arabia Using Concern Based Adoption Model ( CBAM ) Stages of Concern. International Journal of Emerging Technologies in Learning, 14(5), 153-164. https://doi.org/10.3991/ijet.v14i05.8296

[20] Hao, S., Dennen, V. P., \& Mei, L. (2017). Influential factors for mobile learning acceptance among Chinese users. Educational Technology Research and Development, 65(1), 101-123. https://doi.org/10.1007/s11423-016-9465-2

[21] Martin, F. (2011). Instructional Design and the Importance of Instructional Alignment. Community College Journal of Research and Practice, 35(12), 955-972. https://doi.org/10.1080/10668920802466483

[22] Lee, J., \& Jang, S. (2014). A methodological framework for instructional design model development: Critical dimensions and synthesized procedures. Educational Technology Research and Development, 62(6), 743-765. https://doi.org/10.1007/s11423-014-9352-7

[23] Norbert M. Seel, Thomas Lehmann, P. B. and O. A. P. (2017). Instructional Design for Learning: Theoretical Foundations. Rotterdam: Sense Publishers.

[24] Glahn, C., \& Gruber, M. R. (2018). Mobile Blended Learning. In Handbuch Mobile Learning (pp. 303-320). Wiesbaden: Springer Fachmedien Wiesbaden. https://doi.org/10.1007/978-3-658-19123-8 16

[25] Zhang, J., Zhang, L. W., \& Zang, T. Y. (2013). Design of mobile blended learning system based on context-aware. Advanced Materials Research, 756-759(2013), 2019-2023. https://doi.org/10.4028/www.scientific.net/amr.756-759.2019

[26] Huang, R., \& Zhang, H. (2008). Towards a Design Theory of Blended Learning Curriculum. In Hybrid Learning and Education: First International Conference, ICHL Proceedings (pp. 66-78). https://doi.org/10.1007/978-3-540-85170-7

[27] Hack, G. (2016). An Instructional Design Model for Blended Higher Education. Journal of Learning and Teaching in Digital Age (JOLTIDA), 1(2), 2-9.

[28] Biech, E. (2014). ASTD Handbook, 2nd Edition: The Definitive Reference for Training \& Development. Alexandria: ASTD Press.

[29] Bocconi, S., \& Trentin, G. (2014). Modelling blended solutions for higher education: teaching, learning, and assessment in the network and mobile technology era. Educational Research and Evaluation, 20(7), 516-535. https://doi.org/10.1080/13803611.2014.996367

[30] Brandl, K. (2005). Are You Ready to "MOODLE”? Language Learning \& Technology, 9(2), 16-23. https://doi.org/10.5449/idslu-001091490.75

[31] Dougiamas, M., \& Taylor, P. C. (2003). Moodle: Using Learning Communities to Create an Open Source Course Management System. EDMEDIA 2003.

[32] Georgouli, K., Skalkidis, I., \& Guerreiro, P. (2008). A Framework for Adopting LMS to Introduce e-Learning in a Traditional Course, 11(2), 227-240. https://doi.org/10.230 7/jeductechsoci.11.2.227

[33] Govender, I. (2009). The learning context: Influence on learning to program. Computers and Education, 53(4), 1218-1230. https://doi.org/10.1016/j.compedu.2009.06.005

[34] Henderson, J. G. (2011). Learning Through a Disciplined Curriculum Study Approach. Scholar-Practitioner Quarterly, 4(4), 312-315.

[35] Chootongchai, S., \& Songkram, N. (2018). Design and development of SECI and moodle online learning systems to enhance thinking and innovation skills for higher education 
learners. International Journal of Emerging Technologies in Learning, 13(3), 154-172. https://doi.org/10.3991/ijet.v13i03.7991

[36] Melton, J. (2008). Need an LMS? Try the Open Source Package Moodle. Journal of Instruction Delivery Systems, 22(1), 18-21.

[37] Matthew Perkins, J. P. (2006). Using a Course Management System to Improve Classroom Communication. Science Teacher, 73(7), 33-37. Retrieved from https://www.learn techlib.org/p/100421/

[38] Konstantinidis, A., Papadopoulos, P. M., Tsiatsos, T., \& Demetriadis, S. (2011). Selecting and Evaluating a Learning Management System: A Moodle Evaluation Based on Instructors and Students. International Journal of Distance Education Technologies, 9(3), 13-30. https://doi.org/10.4018/jdet.2011070102

[39] "Features - MoodleDocs." [Online]. Available: https://docs.moodle.org/36/en/Features. [Accessed: 18-Feb-2019].

[40] Richey, R. C., \& Klein, J. D. (2007). Design and development research. Mahwah: Lawrence Erlbaum.

[41] Lee, J., Lim, C., \& Kim, H. (2017). Development of an instructional design model for flipped learning in higher education. Educational Technology Research and Development, 65(2), 427-453. https://doi.org/10.1007/s11423-016-9502-1

[42] Barlas, Y. (1994). Model validation in system dynamics. In International System Dynamics Conference.

[43] Richey, R. C. (2005). Validating instruction design and development models. In In: Spector J. M. and Wiley D. A. (Ed.), Innovations in instructional technology: Essays in honor of M. David Merrill (pp. 171-185). Mahwah: NJ: Lawrence Erlbaum Associates.

[44] Han, Y., Tian, L., \& Cheng, W. (2017). Design and Implementation of Mobile Blended Learning Model Based on WeChat Public Platform. MATEC Web of Conferences, 100, 02020. https://doi.org/10.1051/matecconf/201710002020

[45] Debattista, M. (2018). A comprehensive rubric for instructional design in e-learning. International Journal of Information and Learning Technology, 35(2), 93-104. https://doi.org/10.1108/ijilt-09-2017-0092

[46] Sukardjo. (2010). Evaluasi Pembelajaran. Buku Pegangan Kuliah. PPs Universitas Negeri Yogyakarta.

[47] Anderson, L. W., \& Krathwohl, D. R. (2001). A Taxonomy for Learning, Teaching, and Asessing: A Revision of Bloom's Taxonomy of Educational Objectives. New York: Addison Wesley Longman, Inc.

[48] Guglielmino, P.J., Guglielmino, L. M. (2001). Learner characteristics affecting success in electronic distance learning. In H.B. Long \& Associates, 21st century advances in selfdirected learning. Schaumburg: Motorola University Press.

[49] Guglielmino, P.J., Guglielmino, L. M. (2002). Are your learners ready for e-learning? AMA handbook of online learning. New York: American Management Association.

[50] Lucy M Guglielmino, P. J. G. (2003). Identifying learners who are ready for e-learning and supporting their success. Preparing Learners for E-Learning, 13-33.

[51] Caspi, A., \& Gorsky, P. (2005). Instructional Media Choice: Factors Affecting the Preferences of Distance Education Coordinators. Journal of Educational Multimedia and Hypermedia, 14(2), 169-198.

[52] Munawaroh. (2017). The Influence of Teaching Methods and Learning Environment to the Student's Learning Achievement of Craft and Entrepreneurship Subjects at Vocational High School. International Journal of Environmental \& Science Education, 12(4), 665-678.

[53] BADA, \& Olusegun, S. (2015). Constructivism Learning Theory: A Paradigm for Teaching and Learning. Journal of Research \& Method in Education, 5(6), 66-70. 


\section{Authors}

I Kadek Suartama is a doctorate student of Universitas Negeri Malang, Malang, Indonesia. He is currently teaching at the Universitas Pendidikan Ganesha, Singaraja, Indonesia. His research interests are e-learning, multimedia learning, and mobile learning.

Punaji Setyosari is a professor in the post Graduate program of the Department of Education and Technology, Universitas Negeri Malang, Malang, Indonesia. His research interests include research methodologies, evaluation and assessment, instructional media, problem-based learning, and collaborative learning.

Sulthoni is a lecturer in the Department of Educational Technology, Universitas Negeri Malang, Malang, Indonesia. His research interests include instructional media and learning strategies.

Saida Ulfa is a lecturer in the Department of Educational Technology, Universitas Negeri Malang, Malang, Indonesia. Her research interests include mobile learning, instructional media, and learning engineering.

Article submitted 2019-04-08. Resubmitted 2019-06-09. Final acceptance 2019-06-15. Final version published as submitted by the authors. 